IIUC STUDIES

ISSN 1813-7733

Vol.-12 December 2015

(P. 71-86)

\title{
CLT at the Higher Secondary Level in Bangladesh: Theory and Practice
}

\section{Md. Mohib Ullah ${ }^{1}$}

\begin{abstract}
With the progress of time, the aim of teaching and learning English as a Second Language (ESL) or English as a Foreign Language (EFL) changed, and so did the approaches and methods in language teaching. Different methods and approaches emerged and were replaced, influenced or contributed to the emergence of new methods. It is widely acknowledged that one umbrella approach to language teaching that has become the accepted "norm" in this field is the Communicative Language Teaching Approach. This study deals with the theories and practices of CLT at the Higher Secondary level in Bangladesh. Realizing the significance of CLT, The Ministry of Education in Bangladesh made groundbreaking attempts to implement CLT in the new context and also brought some changes in the curriculum in 1990s. Along with attempting to provide a real picture of how CLT is practiced and utilized in an ESL/EFL context, this study focuses on the Practice of CLT approach in Bangladesh. Moreover, this study intends to propose some propositions to be implemented for better practice of CLT in ESL/EFL contexts.
\end{abstract}

Key Words: Communicative Language Teaching (CLT), Higher Secondary level, Bangladesh.

\section{Introduction:}

In the present world dominated by BANA (Britain, Australia and North America) countries, the importance of English and the demand to teach learners a working command of English to satisfy various communicative needs in their real life are greatly noticeable. As a consequence, education administrators in many Asian and African countries have felt an urge to explore and introduce the most recent and best methods of teaching English. In Bangladesh, for example, teachers of English recognize that traditional pedagogy, emphasizing merely the

${ }^{1}$ About the Author: Mr. Md. Mohib Ullah is a Lecturer (On Study Leave) in the department of English Language and Literature, International Islamic University Chittagong. 
acquisition of grammar and vocabulary rather than communicative competence, does not meet the requirements of English learning in an era of integration and globalization.

So The Ministry of Education (MoE), Bangladesh, brought about a revolutionary change in the paradigm of English Language Teaching in the country in late 1990s as it felt that the age old language teaching tradition (GT) was not any longer up to the mark to achieve the desired goal. The change is not only in introducing new textbooks but also a new approach to teaching English commonly known as Communicative Language Teaching (CLT) replacing the earlier method known as the Grammar Translation Method (GT).

In Bangladesh, we see that the national curriculum controls the instructional procedure and the contents of general education: Ministry of Education first designs the national curriculum and thereupon textbooks are developed. The Ministry of Education authorizes National Curriculum Textbook Board (NCTB) to publish textbooks, and the authorized textbooks are then used in the institutional settings. English education is carried out through this procedure.

English Language Teaching Improvement Project (ELTIP), jointly funded by the Government of Bangladesh and Department for International Development (DFID) of the UK in cooperation with National Curriculum Textbook Board (NCTB), have been working to facilitate teaching and learning of English in Bangladesh. It paid significant attention to CLT and introduced the approach in the national English curriculum of the country for the first time in 1990s. In 1997, the communicative English tasks were introduced in the compulsory English Textbooks for the school and college level students in Bangladesh.

It is assumed that CLT is not a term for one particular type of teaching theory, approach or methodology, but an umbrella term for various types of teaching procedures which evolved a couple of decades ago when communication came to be generally recognized as the ultimate goal of language teaching and learning. After providing the dynamic features of CLT, it seems necessary to investigate the current status of the employment of CLT in an EFL context like Bangladesh. This study thereby aims to suggest a desirable future direction for promoting ELT in Bangladesh.

The HSC compulsory English syllabus consists of English for Today (English first paper) and English Grammar and Composition (English second paper). English first paper includes twenty four units that include 
seventy nine lessons. Most of the lessons are on reading comprehension of different issues. On the other hand, English second paper includes different grammatical and writing items. The writing items are on letter, application, dialogue and compositions.

\subsection{HSC Testing Procedure:}

In fact, HSC English Testing focuses on reading and writing skills. A test of one hundred marks is designed for English first paper and it is divided into three parts. Part A includes two reading comprehension passages and there are four questions on each passage. Each question is of five marks. There are two questions on vocabulary in Part B, and each question carries ten marks. In Part three, there are three questions i.e. a substitution table of twelve marks, a rearrangement of fourteen marks and a paragraph of fourteen marks:

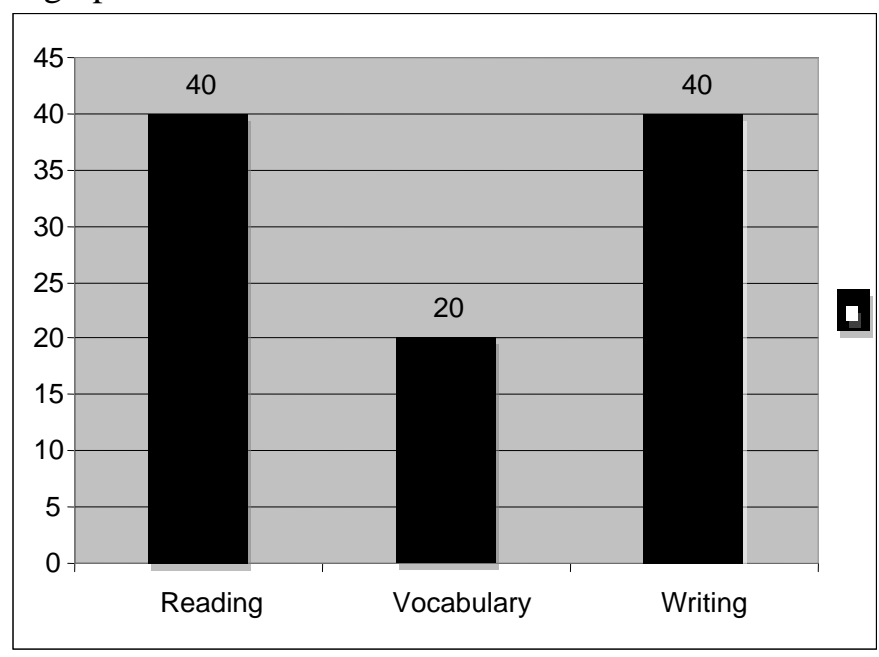

Figure-1: Marks Distribution of English First Paper at Higher Secondary Level

Again, a test of one hundred marks is given for English second paper which aims at testing grammatical and writing skills of the learners. There are two parts in this question paper. Part A includes eight grammatical questions each containing five marks whereas Part B includes questions on writing skill i.e. letter, dialogue and composition writing: 


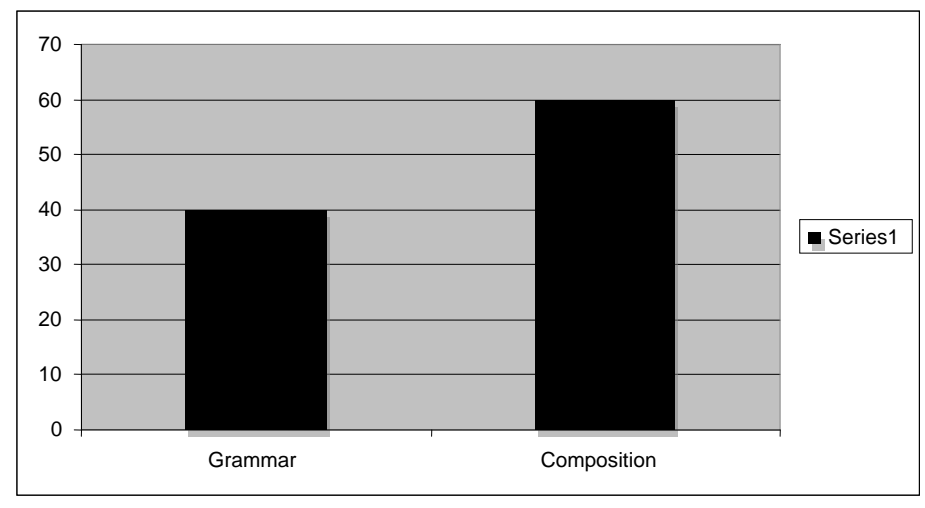

Figure-2: Marks Distribution of English Second Paper at Higher Secondary Level

\subsection{Objective of the study}

Since Communicative Language Teaching (CLT) is unlike the conventional phenomenon in Bangladesh, teachers accustomed to teaching in traditional ways face difficulties in making the classrooms interactive with the tasks and activities integrating the four language skills along with their compatible pragmatic solutions. Besides, it is assumed that there are problems with the syllabus design and testing system as they do not reflect CLT at all. The aim of this study is to explore the present scenario of CLT at the Higher Secondary Level and provide with probable solutions in this regard.

\section{Literature review}

In the very first chapter of Communicative Language Teaching, Littlewood (1981) articulates that one of the most characteristic features of communicative language teaching is that it pays systematic attention to functional as well as structural aspects of language, combining these into a more fully communicative view.

As regards, the communicative curriculum, Breen and Candlin (1980) put forward some key characteristics, and the impact of them is still apparent today. According to them, a curriculum should include five features: (1) content is focused on language knowledge that is personally significant to learners; (2) sequencing is cyclical, rather than step by step; (3) content is subdivided into activities and tasks in which there is interaction, rather than broken down into structures; (4) continuity resides within and between activities, tasks, and themes; (5) choosing directions involves negotiation between learners and learners, learners and teachers, and learners and text—-there is no predetermined route. 
In the learning process of CLT, much focus is given on genuine communication. However, it is very challenging to teachers to determine how to create genuine communication within the classroom setting. Some ELT experts have proposed general principles and practices to help do this. For example, Nunan (1989) suggests the use of "activities [that] involve oral communication, carrying out meaningful tasks, and using language which is meaningful to the learner" as well as the use of "materials [that] promote communicative language use ... [and] arc taskbased and authentic." Brown (1994) proposes that communication is likely to occur in the classroom when: (1) a significant amount of pair work and group work is conducted; (2) authentic language input in real life context is provided; (3) students are encouraged to produce language for genuine, meaningful communication; and (4) classroom tasks are conducted to prepare students for actual language use outside the classroom. Larsen-Freeman (2000) also maintains that it is important "to facilitate small group and paired activities in which students have opportunities to interact. The activities themselves often engage students in communicative tasks such as filling information gaps using authentic materials.”

In order to use language effectively, Hymes (1972) argues learners need to develop communicative competence-the ability to use the language they are learning appropriately in a given social encounter. Arguing against Chomsky (1957), Hymes proposes that knowing a language involves more than knowing a set of grammatical, lexical, and phonological rules. He outlines that CLT is based on the work of sociolinguists.

In the field of research we find that a number of practice-oriented language educators examine Hymes' notion of communicative competence. This examination culminates with Canale and Swain's (1980) elaborate definition of the term (later refined by Canale in 1983). These researchers opine that communicative competence involves grammatical, sociolinguistic, discourse, and strategic competence.

Canale and Swain (1980) make it clear that although "there seem to be no strong theoretical reasons for emphasizing getting one's message across over grammatical accuracy at the early stages of second language learning... some combination of emphasis on grammatical accuracy and emphasis on meaningful communication from the very start of second language study is suggested." Thus it is noted that the definition of communicative competence of Canale and Swain specifically includes 
grammar laying grammatical competence within a more broadly defined communicative competence.

To develop learners' communicative competence in the second language is the target of communicative activities, and in the absence of control of grammar, these activities cannot take place. How this grammar is to be discovered is the point of the difference of the researchers. Some advocate the more traditional presentation of a rule followed by practice. Others believe grammatical awareness will emerge naturally from practice in communicative interaction that has meaning. In either case, teachers still need to know what communication means for classroom practices. The answer is that teachers need to work that out for themselves. As Richards and Rogers (1986) put it:

Communicative Language Teaching is best considered an approach rather than a method. Thus although a reasonable degree of theoretical consistency can be discerned at the levels of language and learning theory, at the levels of design and procedure there is much greater room for individual interpretation and variation than most methods permit.

At the later stage, we see that Savignon (1991, 2002) explains some implications of CLT and emphasizes that it puts the focus on the learner: "Learners communicative needs provide a framework for elaborating program goals in terms of functional competence".

From the above discussion, we find different views of CLT within the theoretical framework of communicative competence proposed by Canale and Swain. However, they consent to the need for meaningful communication to support learning and agree that classroom activities should focus on learners' genuine communicative needs.

\section{The Method of Enquiry}

In an attempt to have a clear idea about the practice of CLT in Bangladesh, the study was conducted in ten colleges (Govt. and nongovernment; urban and rural) of three districts i.e. Chittagong, Cox's Bazar and Bandarban.

Both close-ended statements and open ended questions were used to collect data for this research. Twenty teachers and one hundred seven learners participated in replying the questionnaire. Out of thirty five teachers and two hundred students, twenty teachers and one hundred seven students responded to the questionnaire. Questionnaire having close-ended statements was used to collect data from both students and 
teachers; on the other hand, open-ended questions were used only for teachers. As classroom is the place where students have scope for CLT based practice within institution, emphasize has been given on questionnaire related to classroom practice. Besides, some close-ended statements and open-ended questions regarding teacher and student roles, teaching materials, syllabus and curriculum and testing system have been employed to get better findings.

\section{Data Analysis}

In this section, we have considered different sources of data on classroom activities, teacher and learner roles, syllabus and materials and testing procedures. In the subsequent discussion, these issues are analyzed systematically.

\subsection{Classroom activities}

We know that CLT classroom activities "are often designed to focus on completing tasks that are mediated through language or involve negotiation of information and information sharing" Richards and Rodgers (1986). Little wood (1981) categorizes CLT classroom activities into two types- "functional communicative activities" and "social interaction activities". That is why, it is understandable why the teachers and linguists have been rendering their best effort to improve the classroom activities keeping congruity with the principles of communicative approach. This quest has continued to the present. The following data reveal the classroom scenario at the Higher Secondary Level in Bangladesh.

\begin{tabular}{|l|l|l|l|l|l|l|}
\hline Close-ended & \multicolumn{3}{|c|}{ Learners' reply } & \multicolumn{3}{|c|}{ Teachers' reply } \\
\cline { 2 - 7 } $\begin{array}{l}\text { statements related } \\
\text { to classroom } \\
\text { activities and } \\
\text { environment }\end{array}$ & Agree & $\begin{array}{c}\text { Not } \\
\text { agree }\end{array}$ & $\begin{array}{c}\text { Some } \\
\text { what } \\
\text { agree }\end{array}$ & Agree & $\begin{array}{c}\text { Not } \\
\text { agree }\end{array}$ & $\begin{array}{c}\text { Some } \\
\text { what } \\
\text { agree }\end{array}$ \\
\hline $\begin{array}{l}\text { 1. Classroom reflect } \\
\text { activities reflec } \\
\text { that } \\
\text { communicative } \\
\text { competence is the } \\
\text { expected goal. }\end{array}$ & $17 \%$ & $59 \%$ & $24 \%$ & $21 \%$ & $57 \%$ & $22 \%$ \\
\hline $\begin{array}{l}\text { 2. There is an } \\
\text { attempt to link } \\
\text { classroom } \\
\text { language learning } \\
\text { with language } \\
\text { activities in the }\end{array}$ & $13 \%$ & $71 \%$ & $16 \%$ & $22 \%$ & $68 \%$ & $10 \%$ \\
\hline
\end{tabular}


IIUC Studies, Vol. 12

\begin{tabular}{|c|c|c|c|c|c|c|}
\hline \multirow{2}{*}{\begin{tabular}{lr}
\multicolumn{2}{l}{ Close-ended } \\
statements related \\
to rassroom \\
activities & and \\
environment &
\end{tabular}} & \multicolumn{3}{|c|}{ Learners' reply } & \multicolumn{3}{|c|}{ Teachers' reply } \\
\hline & Agree & $\begin{array}{c}\text { Not } \\
\text { agree }\end{array}$ & $\begin{array}{l}\text { Some } \\
\text { what } \\
\text { agree }\end{array}$ & Agree & $\begin{array}{c}\text { Not } \\
\text { agree }\end{array}$ & $\begin{array}{l}\text { Some } \\
\text { what } \\
\text { agree }\end{array}$ \\
\hline social context. & & & & & & \\
\hline $\begin{array}{l}\text { 3. } \text { Classroom } \\
\text { activities provide } \\
\text { scope for } \\
\text { developing } \\
\text { listening skill. } \\
\end{array}$ & $21 \%$ & $66 \%$ & $13 \%$ & $30 \%$ & $56 \%$ & $14 \%$ \\
\hline $\begin{array}{l}\text { 4. The medium of } \\
\text { lecture in the class } \\
\text { is English. }\end{array}$ & $14 \%$ & $70 \%$ & $16 \%$ & $21 \%$ & $61 \%$ & $18 \%$ \\
\hline $\begin{array}{l}\text { 5. There is scope for } \\
\text { developing four } \\
\text { integrated skills in } \\
\text { the class. }\end{array}$ & $9 \%$ & $79 \%$ & $12 \%$ & $14 \%$ & $72 \%$ & $14 \%$ \\
\hline $\begin{array}{l}\text { 6. Teachers provide } \\
\text { scope for pair } \\
\text { work or group } \\
\text { work in the } \\
\text { classroom. }\end{array}$ & $3 \%$ & $89 \%$ & $8 \%$ & $7 \%$ & $81 \%$ & $12 \%$ \\
\hline $\begin{array}{l}\text { 7. Comprehensible } \\
\text { pronunciation is } \\
\text { sought. }\end{array}$ & $77 \%$ & $9 \%$ & $14 \%$ & $72 \%$ & $14 \%$ & $14 \%$ \\
\hline $\begin{array}{l}\text { 8. There are task } \\
\text { completion } \\
\text { activities in the } \\
\text { class. }\end{array}$ & $2 \%$ & $98 \%$ & $0 \%$ & $2 \%$ & $98 \%$ & $0 \%$ \\
\hline 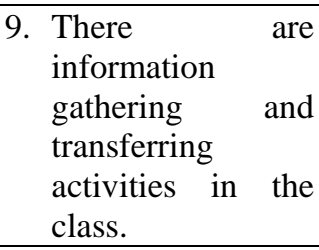 & $35 \%$ & $24 \%$ & $41 \%$ & $50 \%$ & $5 \% \%$ & $45 \%$ \\
\hline $\begin{array}{l}\text { 10. Students are asked } \\
\text { to play role in the } \\
\text { class. }\end{array}$ & $0 \%$ & $100 \%$ & $0 \%$ & $0 \%$ & $100 \%$ & $0 \%$ \\
\hline $\begin{array}{l}\text { 11. Classroom } \\
\text { activities focus } \\
\text { more on accuracy } \\
\text { than fluency. }\end{array}$ & $85 \%$ & $10 \%$ & $5 \%$ & $87 \%$ & $3 \%$ & $10 \%$ \\
\hline
\end{tabular}

Table-1

The above data put forward the fact that our classroom activities are far away from the true parameter of ideal CLT classroom activities. 


\subsection{Teacher and Learner roles :}

Breen and Candlin (1980) maintain that in a CLT classroom a teacher is to "facilitate communication process between all participants in the classroom, and between these participants and the various activities and the texts". They further insist that a teacher "is to act as an independent participant within the learning-teaching group". Other roles assumed for the teachers are needs analyst, counselor and group process manager. In Bangladesh, we observe that instead of being facilitator and monitor, majority of the teachers are engaged in translating reading passages and answering the questions of those passages. In the English Second Paper class, teachers are mostly busy with teaching grammar in "deductive" fashion. They hardly bother CLT guidelines.

Breen and Candlin (1980) hold that "the role of learner as negotiatorbetween the self, the learning process, and the object of leaningemerges from and interacts with the role of joint negotiator...." Instead of relying on the teacher for model, learners have to be at ease with listening to their peers in group work or pair work tasks. It is expected that learners will take a potential responsibility for their own learning. The responses of the teachers and learners in this regard are given below:

\begin{tabular}{|c|c|c|c|c|c|c|}
\hline \multirow{2}{*}{$\begin{array}{l}\text { Close-ended } \\
\text { statements related } \\
\text { to Teacher and } \\
\text { learner roles }\end{array}$} & \multicolumn{3}{|c|}{ Learners' reply } & \multicolumn{3}{|c|}{ Teachers' reply } \\
\hline & Agree & $\begin{array}{c}\text { Not } \\
\text { agree }\end{array}$ & $\begin{array}{l}\text { Some } \\
\text { what } \\
\text { agree }\end{array}$ & Agree & $\begin{array}{l}\text { Not } \\
\text { agree }\end{array}$ & $\begin{array}{l}\text { Somew } \\
\text { hat } \\
\text { agree }\end{array}$ \\
\hline $\begin{array}{l}\text { 1. Teacher roles } \\
\text { facilitate the } \\
\text { communication } \\
\text { process in the } \\
\text { class. }\end{array}$ & $7 \%$ & $82 \%$ & $11 \%$ & $9 \%$ & $81 \%$ & $10 \%$ \\
\hline $\begin{array}{l}\text { 2. Teachers act as } \\
\text { independent } \\
\text { participants } \\
\text { within the } \\
\text { learning- } \\
\text { teaching group. }\end{array}$ & $6 \%$ & $81 \%$ & $13 \%$ & $10 \%$ & $79 \%$ & $11 \%$ \\
\hline $\begin{array}{l}\text { 3. Lack of } \\
\text { teachers' } \\
\text { training affect } \\
\text { class } \\
\text { performance. }\end{array}$ & $85 \%$ & $10 \%$ & $5 \%$ & $82 \%$ & $10 \%$ & $8 \%$ \\
\hline $\begin{array}{l}\text { 4. Teachers act as } \\
\text { counselor. }\end{array}$ & $22 \%$ & $24 \%$ & $54 \%$ & $19 \%$ & $31 \%$ & $50 \%$ \\
\hline
\end{tabular}




\begin{tabular}{|c|c|c|c|c|c|c|}
\hline \multirow{2}{*}{$\begin{array}{l}\text { Close-ended } \\
\text { statements related } \\
\text { to Teacher and } \\
\text { learner roles }\end{array}$} & \multicolumn{3}{|c|}{ Learners' reply } & \multicolumn{3}{|c|}{ Teachers' reply } \\
\hline & Agree & $\begin{array}{c}\text { Not } \\
\text { agree }\end{array}$ & $\begin{array}{l}\text { Some } \\
\text { what } \\
\text { agree }\end{array}$ & Agree & $\begin{array}{l}\text { Not } \\
\text { agree }\end{array}$ & $\begin{array}{l}\text { Somew } \\
\text { hat } \\
\text { agree }\end{array}$ \\
\hline $\begin{array}{l}\text { 5. Teachers } \\
\text { assume } \\
\text { responsibility } \\
\text { for determining } \\
\text { and responding } \\
\text { to learner } \\
\text { language needs. }\end{array}$ & $12 \%$ & $81 \%$ & $7 \%$ & $11 \%$ & $82 \%$ & $7 \%$ \\
\hline 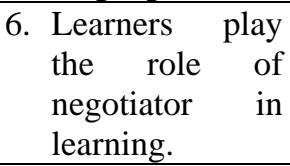 & $2 \%$ & $93 \%$ & $5 \%$ & $4 \%$ & $90 \%$ & $6 \%$ \\
\hline $\begin{array}{l}\text { 7. Learners } \\
\text { actively } \\
\text { participate in } \\
\text { the classroom } \\
\text { activities. }\end{array}$ & $14 \%$ & $66 \%$ & $20 \%$ & $17 \%$ & $65 \%$ & $18 \%$ \\
\hline $\begin{array}{l}\text { 8. They take } \\
\text { responsibility of } \\
\text { their own } \\
\text { learning. }\end{array}$ & $10 \%$ & $85 \%$ & $5 \%$ & $12 \%$ & $80 \%$ & $8 \%$ \\
\hline
\end{tabular}

The above data expose that there is a huge gap between the theory and practice regarding teacher and learner activities. We can find that our classroom is still too much teacher centered rather than learner centered.

\subsection{Teaching materials}

Obviously, the materials of CLT are different form GT based materials. In CLT "we can device communication activities which place emphasis on social as well as functional aspects of communication" Little wood (1981). Functional activities include map reading, describing pictures, following directions and solving problems from shared clues. Activities in social interaction include conversation and discussion sessions, dialogues and role plays, simulations, and debates. Our HSC teaching materials are designed in such a way that our students can gradually achieve communicative competence. From our study, it is noticed that most of the tasks of these textbooks are not practiced in the class as our testing excludes those type of activities. No matter how much efficient textbooks we have, it becomes useless if we cannot involve our students 
in the activities that the texts contain. The findings related to this affair have been presented below:

\begin{tabular}{|c|c|c|c|c|c|c|}
\hline \multirow{2}{*}{$\begin{array}{l}\text { Close-ended } \\
\text { statements related to } \\
\text { Syllabus } \\
\text { materials }\end{array}$} & \multicolumn{3}{|c|}{ Learners’ reply } & \multicolumn{3}{|c|}{ Teachers' reply } \\
\hline & Agree & \begin{tabular}{|l|}
$\begin{array}{c}\text { Not } \\
\text { agree }\end{array}$ \\
\end{tabular} & $\begin{array}{l}\text { Some } \\
\text { what } \\
\text { agree }\end{array}$ & Agree & $\begin{array}{l}\text { Not } \\
\text { agree }\end{array}$ & $\begin{array}{l}\text { Some } \\
\text { what } \\
\text { agree }\end{array}$ \\
\hline $\begin{array}{l}\text { 1. Present textbook is } \\
\text { suitable to develop } \\
\text { communicative } \\
\text { competence. }\end{array}$ & $54 \%$ & $32 \%$ & $14 \%$ & $71 \%$ & $15 \%$ & $14 \%$ \\
\hline $\begin{array}{l}\text { 2. Tasks given in the } \\
\text { textbook is properly } \\
\text { practiced in the } \\
\text { class. }\end{array}$ & $17 \%$ & $67 \%$ & $16 \%$ & $27 \%$ & $52 \%$ & $21 \%$ \\
\hline $\begin{array}{l}\text { 3. Textbook should be } \\
\text { redesigned to make } \\
\text { it more targets } \\
\text { oriented. }\end{array}$ & $27 \%$ & $33 \%$ & $40 \%$ & $37 \%$ & $33 \%$ & $30 \%$ \\
\hline $\begin{array}{l}\text { 4. Recent inclusion of } \\
\text { grammar in curricula } \\
\text { hampers CLT. }\end{array}$ & $13 \%$ & $71 \%$ & $16 \%$ & $12 \%$ & $76 \%$ & $12 \%$ \\
\hline $\begin{array}{l}\text { 5. Grammatical } \\
\text { knowledge promotes } \\
\text { language skills. }\end{array}$ & $67 \%$ & $19 \%$ & $14 \%$ & $69 \%$ & $18 \%$ & $13 \%$ \\
\hline $\begin{array}{l}\text { 6. Besides textbook, } \\
\text { other materials } \\
\text { should be used in } \\
\text { class to make class } \\
\text { more effective. }\end{array}$ & $69 \%$ & $12 \%$ & $19 \%$ & $35 \%$ & $20 \%$ & $45 \%$ \\
\hline
\end{tabular}

Table-3

The data above project that even though the text is reasonably welldesigned, it is not properly used for teaching in class.

\subsection{Testing}

In Bangladesh, any public exam (Junior School Certificate/Secondary School Certificate/Higher Secondary School Certificate exam) means only a comprehensive written test consisting of some reading comprehensions, grammatical items and the writing of essay, letter, and paragraph etc. Humayun (2008) outlines, "Though CLT insists on communicative performance, we still notice that our students are very busy with preparing answers to the probable questions and memorizing them in order to ensure pass marks....... this tendency is ever increasing as our test items are too predictable”. The validity of testing at HSC is 
always seriously criticized as HSC testing is too much predictable and the construction of the test does not truly reflect the standard of communicative language testing.

If we consider the reliability issue at HSC language testing, we have every reason to be worried as there are some major reliability issue related problems. We notice there are problems in test development procedures, test administration, assessment procedures, etc. That is why, According to Rozario (2005), it is felt that "Our examination system (setting of questions, marking papers, learning outcomes, etc) needs to be modified ....."

In a Communicative Language Testing System, we cannot deny the necessity of testing speaking and listening skills. Unfortunately, for some unknown reasons, both of the skills are ignored in our testing system. The present testing system neglects the necessity of testing one's pronunciation, intonation, listening ability, communicative competence, etc. As a result, out of the four vital skills required for a second language learner only partial of his / her language is tested giving an imperfect picture of his/her mastery on SL/FL. "Tests should be designed to reveal not simply the number of items which are answered correctly, but to reveal the quality of the candidate's language performance” Brumfit and Johnson (1985). The result of the investigation regarding the testing system has been put forward here:

\begin{tabular}{|l|c|c|c|c|c|c|}
\hline $\begin{array}{c}\text { Close-ended } \\
\text { statements related to } \\
\text { testing }\end{array}$ & \multicolumn{2}{|c|}{ Learners' reply } & \multicolumn{3}{c|}{ Teachers' reply } \\
\cline { 2 - 7 } & Agree & $\begin{array}{c}\text { Not } \\
\text { agree }\end{array}$ & $\begin{array}{c}\text { Somew } \\
\text { hat } \\
\text { agree }\end{array}$ & e & $\begin{array}{c}\text { Not } \\
\text { agree }\end{array}$ & $\begin{array}{c}\text { Somew } \\
\text { hat } \\
\text { agree }\end{array}$ \\
\hline $\begin{array}{l}\text { 1. Testing system is } \\
\text { encouraging } \\
\text { enough to develop } \\
\text { communicative } \\
\text { competence. }\end{array}$ & $13 \%$ & $71 \%$ & $16 \%$ & $22 \%$ & $68 \%$ & $10 \%$ \\
\hline $\begin{array}{l}\text { 2. Testing tests four } \\
\text { skills of language }\end{array}$ & $7 \%$ & $87 \%$ & $6 \%$ & $11 \%$ & $81 \%$ & $8 \%$ \\
\hline $\begin{array}{l}3 . \text { Listening and } \\
\text { Speaking skills are } \\
\text { not focused in } \\
\text { testing. }\end{array}$ & $90 \%$ & $2 \%$ & $8 \%$ & $93 \%$ & $3 \%$ & $4 \%$ \\
\hline $\begin{array}{l}4 . \text { Testing aims at } \\
\text { providing scope } \\
\text { for students to } \\
\text { secure good } \\
\text { marks. }\end{array}$ & $85 \%$ & $10 \%$ & $5 \%$ & $87 \%$ & $3 \%$ & $10 \%$ \\
\hline
\end{tabular}




\begin{tabular}{|c|c|c|c|c|c|c|}
\hline \multirow{2}{*}{\begin{tabular}{|c|} 
Close-ended \\
statements related to \\
testing
\end{tabular}} & \multicolumn{3}{|c|}{ Learners' reply } & \multicolumn{3}{|c|}{ Teachers' reply } \\
\hline & Agree & $\begin{array}{c}\text { Not } \\
\text { agree }\end{array}$ & $\begin{array}{c}\text { Somew } \\
\text { hat } \\
\text { agree }\end{array}$ & e & $\begin{array}{c}\text { Not } \\
\text { agree }\end{array}$ & $\begin{array}{c}\text { Somew } \\
\text { hat } \\
\text { agree }\end{array}$ \\
\hline $\begin{array}{lr}\text { 5. Question } & \text { pattern } \\
\text { should } & \text { be } \\
\text { modified } & \text { that } \\
\text { students } & \text { are } \\
\text { motivated } & \text { to } \\
& \text { develop four skills } \\
\text { of language. }\end{array}$ & $92 \%$ & $5 \%$ & $3 \%$ & $91 \%$ & $5 \%$ & $4 \%$ \\
\hline
\end{tabular}

Table-4

The data provided above reveal that our HSC language testing system is seriously flawed and is far away from Communicative Language Testing system.

\section{Findings of the open-ended questions}

In response to the question no. one (1), 79\% teachers argue that CLT aims at developing communicative competence and it should cover all four skills. Without gaining competence in four skills, none can learn to communicate effectively. While replying to the question no. two (2), $87 \%$ teachers say that the classes mostly emphasize on reading skill because the traditional system of conducting classes still influences teaching procedures. 91\% teachers, in response to the question no. three (3), say that the role of teachers in class should be of initiators or guides. Question no. four (4) discloses that 94\% teachers believe there is lack of trained teachers for CLT. For facilitating better practice in CLT, there is no alternate to teachers trained on CLT. Without knowing the strategies that CLT propose, no teacher can teach properly. In answer to the question no. five (5), $88 \%$ teachers mention it is obviously government which should take steps to train teachers for the best practice of CLT. As regards the question no. six (6), 93\% teachers opine that CLT is a practice based system of teaching that demands a good environment in class and outside the class so that students get better privilege for practice. In reply to the question no. seven (7), 88\% teachers mention that the appropriate syllabus for teaching CLT is Notional-functional syllabus. While answering the question no. eight (8), 91\% teachers articulate that to tell the truth, textbook is the only source of practice materials in our country. But they think they should include more suitable materials for the smooth progress of CLT. The response to the question no. nine (9) exposes that 83\% teachers think students' examoriented study really affects CLT. Because of this attitude, they do not 
put emphasize on developing communicative competence. On the other hand, they think more about securing good marks in the exam. While replying to the question no. ten (10), 92\% teachers opine that our exam only tests reading and writing skills but doesn't take any test of listening and speaking skills which are very essential for communication. As most of the students take preparation targeting exam, testing of listening and writing skills will encourage students to give emphasize on them.

\section{Conclusion}

This paper has made a discussion on the theoretical aspects of CLT and the present activities to implement it in Bangladesh. Besides, it also pays attention to the limitations such as inadequate choice of the notionalfunctional approach, lack of trained teachers, insufficient classroom activities, inadequate or less standard materials and faulty testing system, etc. In order to get the best out of CLT, it is crucial to bring an effective change in classroom activities and roles of teachers and learners in order that meaningful and real communication can be ensured. Apart from these, developing teaching materials and innovative use of them, redesigning testing system that may help to learn real life communication are also very significant to ensure successful practice.

\section{Recommendations}

The recommendations for effective practice of CLT in Bangladesh are given below:

i. It is important for the teachers to make the classroom environment suitable so that different activities such as group work, pair work, role play, information transfer, etc. can be properly executed.

ii. If the sizes of classes are unusually large, they should be divided into small groups for the convenience of successful monitoring and corrective feedback of communicative activities.

iii. It is necessary for the teachers to have tolerant view and encouraging tone while dealing with learners that their English phobia can be removed and confidence can be enhanced.

iv. It is crucial for teachers to motivate learners both intrinsically and extrinsically for practicing communicative activities inside and out of classroom.

v. Teachers should design lectures in such a way that there are activities to facilitate listening and speaking skills.

vi. Teachers should be properly trained that they can be aware of their proper roles in class and acquainted with the real processes of teaching in CLT approach. 
vii. There should be sufficient arrangement of different kinds of seminars, symposia and training sessions to make the teachers oriented with new backdrops and settings of CLT.

viii. Materials should be developed in such a way that they will focus on meaningful and real life communication.

ix. While redesigning teaching materials in future, it is crucial to include more contextualized and interesting topics to bring out better performance from learners.

$\mathrm{x}$. Testing system should be modified that it tests four skills of language for better practice of CLT

xi. Questions that require communicative activities to prepare answers should be included in testing in order that learners become extrinsically motivated to practice them extensively.

\section{$\underline{\text { References }}$}

Breen, M. \& Candlin, C. (1980) The essentials of a communicative curriculum in language teaching. Applied Linguistics, 1 (2), 89-112.

Brown, H. D. (1994) . Principles of language learning and teaching. Englewood Cliffs, NJ: Prentice Hall Regents.

Brumfit, C.J. \& Johnson, K. (1985) The Communicative Approach to Language Teaching. Walton Street, Oxford OX2 6DP, England Oxford University Press

Canale, M. \& Swain, M. (1980) Theoretical bases of communicative approaches to second language teaching and testing. Applied Linguistics, 1 (1), $1-47$.

Canale, M. (1983). From communicative competence to communicative language pedagogy. In Richards and Schmidt (eds.), Language and communication. London: Longman.

Chomsky, N. (1957). Syntactic structures. The Hague: Mouton.

Hymes, D. (1972). On communicative competence. In Pride and Holmes (eds.), Sociolinguistics. Harmondsworth: Penguin.

Kabir, H. (2008). How validity is ensured in our language test: A Case Study. IIUC Studies, 5

Larsen-Freeman, D. (2000) Techniques and principles in language teaching. Oxford University Press.

Littlewood, W.(1981) Communicative Language Teaching. Cambridge: Cambridge University Press.

Nunan, D.(1989). Designing tasks for the communicative classroom. Cambridge: Cambridge University Press. 
Richards, J. C. \& Rodgers, T. S.(1986). Approaches and methods in language teaching. Cambridge: Cambridge University Press.

Rozario, B. J. (Fall, 2005). Teaching of English in Bangladesh in Secondary and Higher Secondary Levels. Seminar Paper presented in 'The Effective Teaching of English in Bangladesh: Policy, Pedagogy and practices', Organized by Department of English, Stamford University, Dhaka, Bangladesh.

Savignon, S. J. (1991).Communicative language teaching: State of the art. TESOL Quarterly, 25 (2), 261-77.

Savignon, S. J. (2002).Communicative curriculum design for the 21st century. English Teaching Forum, 40 (1), 2-7.

\section{Appendix-I (open-ended questions)}

1. Do you think CLT should cover all four skills? Give your opinion.

2. Which skill is mostly emphasized in class?

3. What should be the role of teachers in CLT?

4. Do you feel lack of trained teachers? Please make comment.

5. Do you think Govt. should take steps for teachers training? Please leave your opinion.

6. How does the social factors/environment influence CLT?

7. What type of syllabus will be suitable for CLT teaching?

8. What's your opinion about course materials for CLT?

9. How does students' exams oriented attitude of study affect CLT?

10. What changes should be brought in testing system in our country to adapt it to CLT? 